KYIV-MOHYLA

HUMANITIES JOURNAL

KYIV-MOHYLA SCHOLARLY PEER-REVIEWED JOURNALS

Historically Informed Performance in Today's Ukrainian Culture

Author(s): Olena Zhukova

Source: Kyiv-Mohyla Humanities Journal 6 (2019): 203-207

Published by: National University of Kyiv-Mohyla Academy

http://kmhj.ukma.edu.ua/ 


\title{
Historically Informed Performance in Today's Ukrainian Culture
}

\author{
Olena Zhukova \\ National Music Academy of Ukraine, Chamber Music Department
}

In the modern period in Ukrainian music culture early music and historically informed performance (HIP) has maintained the status of an "élite art." The Early Music Department at the National Music Academy of Ukraine (MNAU) was established more than two decades ago, initially headed by harpsichord professor Svitlana Shabaltina, and later by Olha Shadrina-Lychak. Music education at the National Music Academy is concentrated mainly around the harpsichord due to the lack of other period instruments. Despite this, the "Open Opera" project initiated its activities with Purcell's Dido and Aeneas and is continuing with Handel's Acis and Galatea. The "Ensemble Music of the Baroque Era" course for string players, given by Alexander Horolsky, was begun at NMAU only last year (2018).

The instrumental inventory at NMAU is not very rich: it consists of Bizzi's Frenchtype harpsichord and a harpsichord and spinet made by the former-GDR Lindholm factory. Since 2010, a harpsichord class has been offered as an optional subject at the Reingold Glière Kyiv Music Institute (Olena Zhukova). The harpsichord is also taught at the Children's Music Academy and in some music schools (headed by Natalia Fomenko and Natalia Sikorska). For many years harpsichord classes at the Glière Academy used an inferior Lindholm instrument, but this year the school acquired a new instrument, a historical copy of an Italian eighteenth-century harpsichord by noted maker Alberto Colzani. The following harpsichords and spinets exist in private collections, and are often used in concerts: a Marc Ducornet French-Flemish harpsichord; a French-type harpsichord made by Ukrainian maker Dmytro Tytenko from a Ducornet kit; Fred Bettenhausen's spinet; two instruments by Russian maker Dmitrii Belov (a spinet Michael Bolton copy and a double-manual harpsichord Rueckers copy, both in private use), and a French-type Taskin copy, made by Netherland's maker Gerrit Klop. Spinets and harpsichords made by Lindholm are found in some small concert-halls and music schools. There are some harpsichordists who perform at the National Organ Hall (on the Zuckermann double-manual Flemish harpsichord); Academy students and graduates perform solo, in ensembles and in orchestras. This is not easily achievable as concert halls usually do not have harpsichords, so musicians have to bring their own instruments. There are also some ensembles that put on early music concerts and study baroque instruments and the baroque style on their own initiative, but again, apart from the harpsichord no other early instruments are officially taught in Ukraine as a main subject. Alas, concert appearances of early music performers are not frequent even in Kyiv and they are less common in other Ukrainian cities. Though, thanks to 
the enthusiasm of early music lovers and professional musicians, baroque music, both Ukrainian and Western European, has sounded in Ukraine more frequently. This is why, regrettably, the vast majority of academic musicians in Ukraine still do not understand the importance of HIP. Such individuals often believe that the harpsichord is an inferior species of piano, and quite often one may see on stage an embarrassing harpsichord performance by those who never underwent professional training on the instrument. On the other hand, there are annual early music festivals that take place in Lviv and Sumy; The Italian Baroque Music Festival was begun in Kyiv a few years ago by the Italian Embassy in Ukraine and the Italian Cultural Center. There are also Philharmonic Societies in all regional centers of Ukraine, the National Philharmonic and House of Organ and Chamber Music in Kyiv, Dnipro, Bila Tserkva, Lviv, and Kharkiv. In 2007 the Philharmonic society in Kharkiv purchased a Ducornet harpsichord, setting the precedent for having a harpsichord in a concert-hall. "The music atmosphere of Kyiv contributed to the progress of HIP," mentions Ukrainian harpsichordist, Professor Svitlana Shabaltina. "Thus, master classes of leading performers, such as Elżbieta Stefańska (Poland), Władysław Kłosiewicz (Poland), Jacques Ogg (The Netherlands), Bernhardt Billiter (Switzerland), Andreas Steier (Germany) became possible."1

Early music is not a mainstream direction for concert life in Kyiv, but interest in it is quite constant thanks to the activity of a few early music enthusiasts. Performing harpsichordists in Ukraine also usually teach the harpsichord. The analysis of music compositions and the study of theoretical literature, mentioned above, are an important part of a musician's work, in the teaching process even more so than in the regular work of a musician-performer. No need to mention that students' repertoires often inspire teachers as well and vice versa. As treatises are mainly available in their original languages, their study also depends on the language skills of students and teachers. Often the teacher becomes a "transmitter" of the information to students, who do not know foreign languages well enough. Together with information learned at master classes abroad, this accounts for the content of classes. This is also one of the reasons why treatises are not consequentially taught in the education process; another reason is that the harpsichord becomes a main subject only at the masters and postgraduate levels. Prior to that, the harpsichord is only an additional subject, which often presents only an outline of HIP for academic musicians, or mainly concentrates on practical lessons. A limited number of music stores and their limited assortment also hinders consistent study. The most popular in this field are concise important books by Francois Couperin and Nikolaus Harnoncourt, in particular, Tables of ornaments from various sources, translated both into Ukrainian and Russian. More substantial sources, such as Carl Philipp Emmanuel Bach's Versuch über die wahre Art das Clavier zu spielen and Johann Joachim Quantz's Versuch einer Anweisung die Flöte traversiere zu spielen treatises, Continuo playing according to Handel, with comments by David Ledbetter, or Colin Booth's research, usually are learned on personal initiative. The choice of foreign

1 Svitlana Shabaltina, Klavesin skvoz veka. Zapiski ispolnitelia [Harpsichord Through the Ages.

Notes of a Performer] (Kyiv: Ukrainskyi priorytet, 2013), 108. 
language often depends on the field of the scholar's research, which makes Ukrainian articles and $\mathrm{PhD}$ dissertations very important sources of information. The most notable are a book of essays by harpsichordists Svitlana Shabaltina and a $\mathrm{PhD}$ theses by Natalia Sikorska, entitled "Baroque Keyboard Music in the Second-Half 19th Century Editions: The Establishment of Historically Informed Performance," and by Olha ShadrinaLychak "Non-Measured Prelude as Representative of the French Harpsichord Style of the $17^{\text {th }}$ - Beginning of the 18th Centuries: Aspects of the Performer's Interpretation" (all in Ukrainian). Naturally, in the study of this field any works on various issues of early music space were carefully studied and many articles were written as part of the preparation. British harpsichordist and harpsichord maker Colin Booth states: “...for truly 'early' music...such a [clean] score may well not, on its own, give today's musicians the information they need to produce a performance which goes the way the composer had in mind." ${ }^{2}$

Various programs consist of English, French, German, and Italian music, as of newly written music. Despite the great lack of baroque instruments here, musicians are enjoying playing baroque music on modern instruments, using gut strings and baroque bows. It is quite a problem to acquire a harpsichord: travel expenses make the acquisition of an instrument from abroad very expensive.

However, cultural life is very active here: very interesting master classes and concerts have taken place at the Music Academy by (in chronological order) professors from Schola Cantorum Basiliensis, Andreas Steier, Jacques Ogg. Christopher Stambridge and others have shared their substantial theoretical and practical knowledge with the fledgling early music school in Kyiv. Alexander Koshelev, a baroque oboe player from London, has made an audio-recording in collaboration with Ukrainian musicians. ${ }^{3}$ Students of the National Music Academy (the entire harpsichord class, which had a lone Lindholm spinet for practice) won the Baerenreiter prize at the prestigious Bachcompetition in 2002. They also performed at the Utrecht Music Festival (Fringe and Fabulous Fringe) and won first prize at the Wanda Landowska competition in Italy (2011-2018).

The early music revival here in Ukraine has a very special history. One of the major discoveries of the new Ukrainian musicology was a discovery by Nina HerasimovaPersydska, who is involved in the field of the study and performance of the choir pieces of Mykola Dyletskyi. It was received enthusiastically because the choir tradition in Ukraine is very powerful and venerable. But generally people have made their first attempts at HIP here quite cautiously. We suggest that there can be two explanation: the Soviet Union strictly limited every display of intellectual freedom, so baroque music with its exaggerated emotions, jazzy improvisational patterns, and swing rhythms was very undesirable. Thus, the huge part of the early music repertoire, including such pearls as Bach cantatas, was left outside of active use. The second possible reason 
is that as in an every unexplored field, the criteria of good or bad were blurred. So sometimes an unusual manner of performance or unequal temperament could be taken as something unprofessional. Nevertheless, the personal efforts of enthusiasts caused great things happening in this field. The early music revival in Ukraine has some specific features. This is because professional music in the baroque era was mainly choir music, and the instrumental baroque tradition in Ukraine was very close to folkloric roots. This is why this process in Ukraine has much in common with folklore. This very special combination of professional early music and folklore in the field of the early music revival is part of the "national awakening" and "national mythology," turning the artistic position to the way of life. Despite the temporary priority of Saint-Petersburg and Moscow as political and cultural centers of the area in the 18th and 19th centuries, we should not forget the times when Ukraine was the gate of Europe to Russia, which allowed many progressive phenomena to appear in Russia, and when great artists of Ukrainian origin brought fame to Russia with their work at the emperor's court: Dmytro Bortnianskyi, Maksym Berezovskyi, Yelyzaveta Bilohradska. The revival in this case suggests serious archival work together with practical invention and improvisation. The representatives of this point of view are, for example, art critic and kobza player Taras Kompanichenko and the "Khoreia Kozatska" ensemble; interesting information about the crossroads of folklore and the baroque are presented in the documentary film Dreaming Up the Past: Early Music in Ukraine (2011) by lute and guitar player Oleh Timofeiev. "A 'normal' early music movement as it is found in Europe or North America is barely present in Ukraine. But there is something else, something arguably a lot more alive and definitely much more connected to the search for cultural identity by this nation and its people" - Oleh Timofeiev observed in 2009. ${ }^{4}$ Since then many things have changed, but that special spirit is still present and represents a separate branch of the early music revival. These processes are somewhat similar to the "method of attempts and errors," which took place in Europe since the beginning of the 2oth century: the names of Arnold Dolmetch and Wanda Landowska are famous at the helm of the early music revival, followed by the more authentic Gustav Leonhard, Franz Bruggen, the brothers Kuijken, and others.

Summarizing all of the above observations, one can say that early music and HIP in Ukraine, despite its elite or, vice versa, folk character, has developed and shown remarkable perspective and potential. The level of education in this field has grown together with audience interest and the appearance of scholarly works on the subject. Every year brings more early music department alumni, gives birth to new early music ensembles, and most importantly, brings Ukraine closer to Western European trends in the early music field, at the same time preserving its national characteristics, conditioned by historical, social, and geographical factors. This is why we can consider the Ukrainian early music school not as a consistent phenomenon, but as an interesting and inspiring process. 


\section{(7)}

Olena Zhukova, $\mathrm{PhD}$, is an associate professor at the National Music Academy of Ukraine and head of the harpsichord class at the Gliere Music Institute. She is Laureate of numerous international competitions. Olena Zhukova has performed numerous harpsichord and piano concerts as a solo-player, accompanist, member of ensemble, chamber, and symphony orchestras. She has also appeared as an organist in noted music halls in Ukraine and abroad (Argentina, UK, Norway, the Netherlands, South Korea, France, USA, and Hungary). As a part of the Two violins project she represented Ukraine at the Winter Olympic games in Pyeongchang and Seoul (February 2018), and the Youth Olympic games (Buenos Aires, Argentine). 